\title{
Whole-body fuel selection in ruminants: nutrient supply and utilization by major tissues
}

\author{
BY ISABELLE ORTIGUES AND ANNE-LAURE VISSEICHE \\ Laboratoire Croissance et Métabolismes des Herbivores, INRA, Theix, \\ 63122 Saint Genès Champanelle, France
}

\section{Sélection de substrats énergétiques par le corps entier chez les ruminants: apport et utilisation de nutriments par les principaux tissus}

\begin{abstract}
RÉSUMÉ
L'utilisation de l'énergie par l'animal dépend de l'utilisation de l'énergie par les différents tissus corporels. Chez les ruminants, les viscères drainés par le sang portal et le foie représentent respectivement jusqu'à 12 et $2 \%$ du poids vif, mais contribuent pour $16-29 \%$ et $17-31 \%$ aux dépenses énergétiques totales. A l'opposé, la contribution des masses musculaires $(35-50 \%$ du poids corporel) aux déponses n'est que de $8-16 \%$. L'augmentation de la production de chaleur par l'animal entier, avec le niveau d'alimentation, provient pour $17-56 \%$ des viscères drainés par la veine porte, pour $16-44 \%$ du foie, et pour $5-7 \%$ de la carcasse. Ces incréments varient avec la nature du régime alimentaire, et donc, avec le type des nutriments disponibles pour les tissus. Les objectifs de cette revue sont de décrire quantitativement l'influence du niveau d'alimentation et de la composition du régime alimentaire (d'après les teneurs en cellulose brute et en matières azotées totales) sur l'apporten nutriments aux principaux tissus corporels (viscères drainés par le sang portal, foie, et train arrière), et leurs flux nets dans ces tissus. Pour ce travail, nous avons compilé les résultats de la littérature obtenus chez les bovins et ovins en croissance, et chez les brebis adultes, non lactantes et non gestantes, avec des techniques de différences artério-veineuses in vivo. Nous avons établi des équations de régression dans la mesure du possible, entre l'énergie métabolisable ingérée, la composition du régime alimentaire et les apports et flux de nutriments. Les nutriments étudiés étaient les principaux acides gras volatils (acétate, propionate, butyrate), le glucose, le lactate, les corps cétoniques, les acides gras libres, l'ammoniaque, l'urée et l'azote- $\alpha$-aminé. Les résultats obtenus au niveau des tissus sont intégrés, et les conséquences sur l'utilisation de l'énergie par l'animal entier sont discutées.
\end{abstract}

Whole-body energy utilization by ruminants varies with plane of feeding and diet composition which modulate the amounts of and the balance between digestion endproducts. For example, efficiency of energy utilization is generally low (about 0.4 ) with forage diets for which the percentage of energy absorbed as volatile fatty acids averages 66 (33 acetate, 14 propionate and $19 n$-butyrate) and where amino acids, long-chain fatty acids and glucose account for 22, 8 and 4 respectively. By contrast, efficiencies are higher with maize-based concentrate diets (about 0.5 ) for which the 
corresponding percentages change to $50(19,18$ and 13), 24, 10 and 16 (Institut National de la Recherche Agronomique, 1978). These nutrients are absorbed and used by body tissues which have specific requirements for energy (Ortigues \& Doreau, 1995) and nutrients (Forbes \& France, 1993). In ruminants, the portal-drained viscera (PDV), the liver and muscles represent $5-11,1-2.5$ and $35-50 \%$ body weight respectively but account for 16-29, 17-31 and about $16 \%$ of whole-body energy expenditure respectively (Ortigues, 1991).

The main objective of the present review is to establish, using published work based on in vivo arterio-venous techniques, predictive quantitative relationships that describe the influence of changes in the level of intake and diet composition, evaluated by the crude fibre $(\mathrm{CF})$ and crude protein $(\mathrm{N} \times 6.25 ; \mathrm{CP})$ contents, on energy requirements of the major body tissue compartments and on partition of net nutrient use by these tissues. The secondary objective is to relate these changes to those of whole-animal energy metabolism. A better understanding of nutrient use by tissues should help to identify means of improving the efficiency of energy utilization for a given animal production system.

\section{DESCRIPTION OF DATA}

The present work was based on data from growing cattle and sheep; these data did not show any clear quantitative differences when expressed on a metabolic body weight $\left(\mathrm{kg}^{0.75}\right)$ basis and they had similar variability. Data were collected from a total of eighty-six publications ( $52 \%$ cattle), describing 164 different nutritional situations $(57 \%$ cattle) in growing cattle (weight ranging from 107 to $467.5 \mathrm{~kg}$ ) as well as in growing or adult sheep ( $25 \cdot 1-73.8 \mathrm{~kg} ; 23.6 \%$ growing lambs). Cattle were fed between 314 and 1210 $\mathrm{kJ}$ metabolizable energy (ME)/d per $\mathrm{kg}^{0.75}$, with $90 \%$ of the data evenly spread across the above maintenance feeding levels. Cattle data were evenly spread across all $\mathrm{CF}$ levels. Sheep were fed between 184 and $996 \mathrm{~kJ} \mathrm{ME} / \mathrm{d}$ per $\mathrm{kg}^{0.75}$ but most (78\%) of the

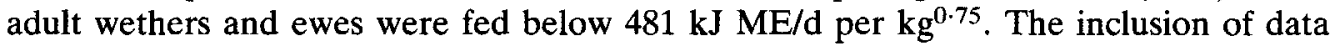
from mature sheep was justified by the fact that they were representative of near or below maintenance conditions. The majority of sheep received forage diets $(62 \%$ of the ovine diets contained at least $300 \mathrm{~g} \mathrm{CF} / \mathrm{kg}$ ). The CP content for $74 \%$ of the cattle and sheep was evenly spaced between 100 and $200 \mathrm{~g} / \mathrm{kg}$. When forage diets were used, they were mostly based on lucerne (Medicago sativa) hay (59\%), and to a lower extent on grass hays $(32 \%)$ or silages $(9 \%)$. With concentrate diets, the main ingredient $(96 \%$ of those diets) was maize. Generally, high levels of feeding ( $>837 \mathrm{~kJ} \mathrm{ME} / \mathrm{d} \mathrm{per} \mathrm{kg}^{0.75}$ ) were achieved with high-concentrate diets, such that the metabolizable energy intake (MEI) and CF were significantly and negatively correlated $(r-0.47)$. A slight positive correlation ( $r$ 0.33) was also noted between CF and CP since high-forage diets were generally based on protein-rich legume hays. No correlation existed between MEI and $\mathrm{CP}$ levels. It should be noted that data obtained on fasting animals were not included in the data-set.

Substrates considered were acetate, propionate, $n$-butyrate, glucose, L-lactate, nonesterified fatty acids (NEFA), $\beta$-hydroxybutyrate as well as $\alpha-\mathrm{NH}_{2}-\mathrm{N}$, urea-N and $\mathrm{NH}_{3}-\mathrm{N}$. The last two metabolites were included as they incur specific energy requirements at the hepatic level. Other substrates, especially lipids, were not considered because of insufficient data. $\mathrm{O}_{2}$ was also included. Data related to PDV and liver were 
analysed by multiple linear regressions with MEI, CF and CP levels as the independent variables. No multiple-regression analysis could be established for the hindquarters except for blood flows because of insufficient data. Interpretation of results was based on correlation coefficients and slopes for each independent variable which were tested using the Student's $t$ test. Conclusions were modulated by the confounding effect that existed between high MEI and maize-based concentrate diets, as well as between high CF levels and lucerne diets. Since the range of MEI data was wider than that of CF, it is likely that some of the CF effects were attributed to feeding level.

Detailed description of the calculated regression equations is available from the author. The present paper discusses only the effects which have been found to be significant as well as some of the major points raised by the data. For the purpose of illustrating some of the effects predicted by the regressions, two levels of MEI (481 and $962 \mathrm{~kJ} / \mathrm{d}$ per kg $\left.{ }^{0.75}\right)$, two levels of dietary CF (100 and $350 \mathrm{~g} / \mathrm{kg}$ ) and of dietary CP (100 and $150 \mathrm{~g} / \mathrm{kg}$ ) are considered.

\section{EFFECT OF FEEDING LEVEL}

\section{Nutrient supply to the portal-drained viscera}

Because of the anatomical position of PDV, metabolism of these tissues is sustained by the supply of both endproducts of digestion and arterial-blood metabolites, as shown for acetate (Bergman \& Wolff, 1971; Seal \& Reynolds, 1993), glucose (Piccioli Cappelli et al. 1993) and amino acids (MacRae et al. 1993). Of the total endogenous plus dietary (endproducts of digestion, assimilated to MEI) energy supply to PDV, $83-87 \%$ is of endogenous origin.

Feeding level generally alters the amount but not the proportions of the endproducts of digestion, except in the case of maize-based diets where, at high intakes, larger proportions of maize starch escape rumen fermentation and are absorbed as glucose by the small intestine (Ortigues \& Doreau, 1995). On the other hand, supply of arterialblood metabolites increases with intake, mainly as a result of a rise in portal blood flow (Table 1, equation 1), as already widely documented (Ortigues, 1991). The predicted arterial propionate and glucose levels were higher and NEFA concentrations were lower at the higher intake (Fig. 1(a)). The first two predictions are probably more indicative of increased dietary proportions of maize-based concentrates than of a direct effect of intake (Reynolds \& Huntington, 1988a,b). Consequently, the higher total energy supply to PDV tissues at the higher intake was associated here with proportionally higher propionate and glucose supply and lower arterial NEFA supply.

\section{Net nutrient fluxes through portal-drained viscera}

Generally, net absorption across PDV was higher at the higher intake $(P<0.05)$ for all nutrients, except glucose, NEFA and urea (Fig. 2(a)), in agreement with Reynolds $e$ al. $(1991,1992 b, 1993 a, b)$ and Burrin et al. (1991). These effects were mainly associated with changes in blood flows.

The net absorption of glucose predicted at low MEI-low CF content was changed to a net uptake by the PDV at the higher intake (Fig. 2(a)); similarly there was net glucose uptake by the PDV at the high-CF-diet intake, probably associated with higher glucose requirements of an increase in gut mass (Reynolds et al. 1991, 1992a). Limited 


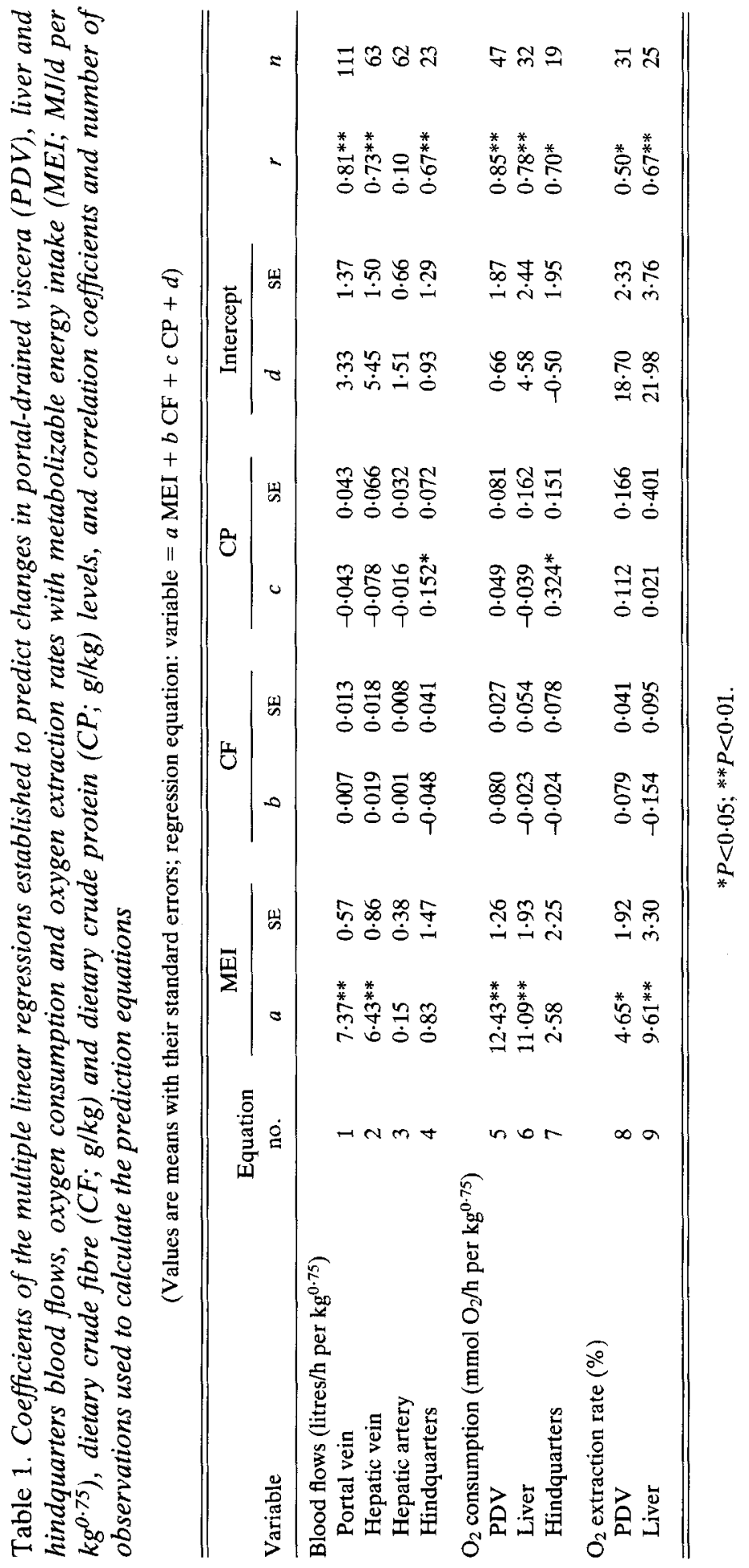


MEI $\left(k J / d\right.$ per $\left.k^{0.75}\right) \ldots$

481

(a) Arterial flow

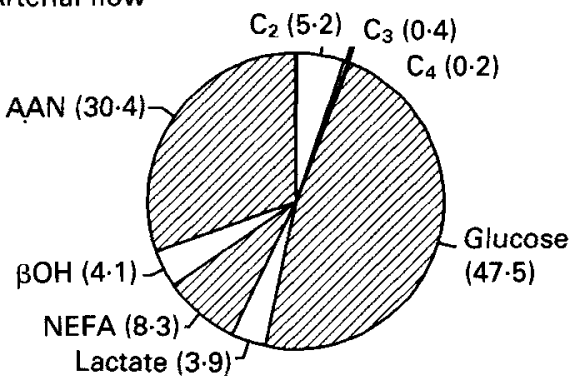

(b) Net PDV flux

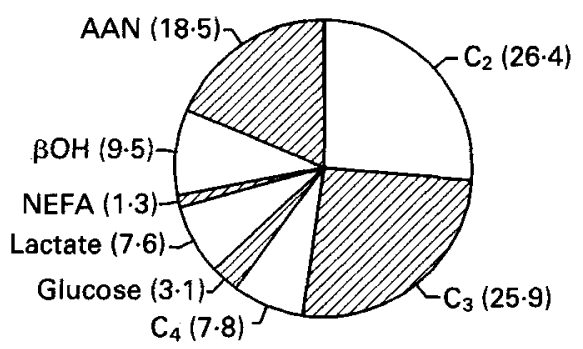

(c) Hepatic inflow

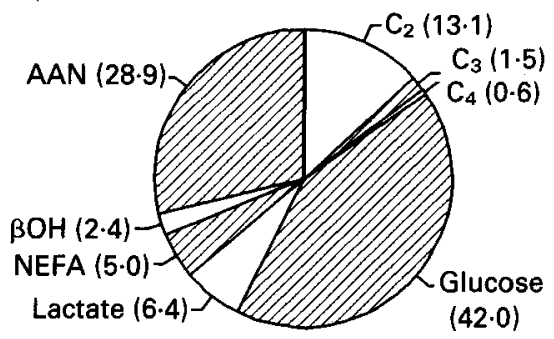

(d) Hepatic outflow

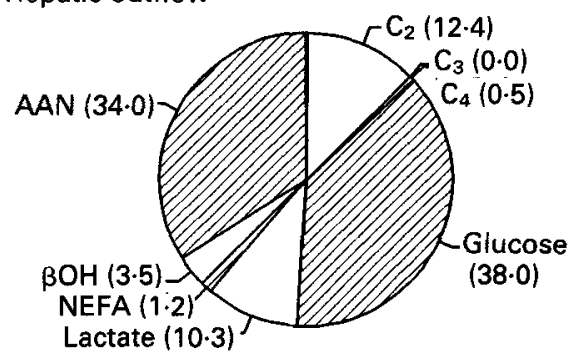

962
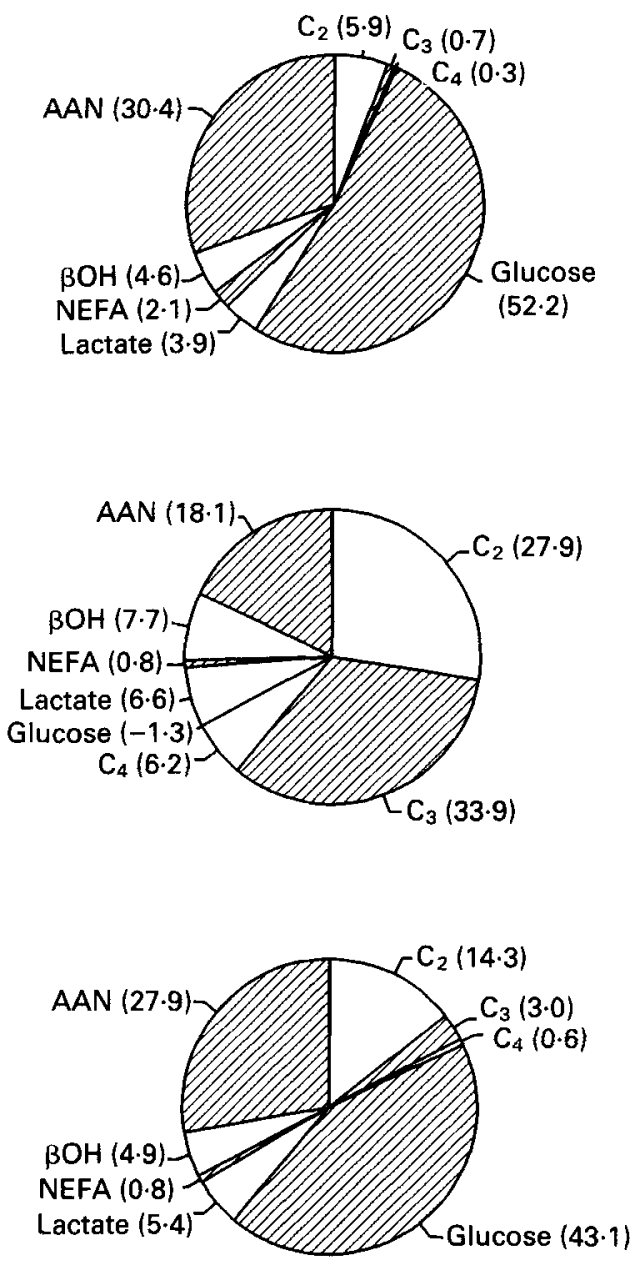

Fig. 1. Effects of metabolizable energy intake (MEI at 481 and $962 \mathrm{~kJ} / \mathrm{d}_{\text {per }} \mathrm{kg}^{0.75}$ ) at constant dietary crude fibre $(100 \mathrm{~g} / \mathrm{kg}$ ) and crude protein (nitrogen $\times 6.25 ; 100 \mathrm{~g} / \mathrm{kg}$ ) contents on the predicted energetic contributions (\%; values shown in parentheses) of acetate $\left(C_{2}\right)$, propionate $\left(C_{3}\right), n$-butyrate $\left(C_{4}\right)$, glucose, lactate, non-esterified fatty acids (NEFA), $\beta$-hydroxybutyrate $(\beta \mathrm{OH})$, urea- $\mathrm{N}, \mathrm{NH}_{3}-\mathrm{N}$ and $\alpha$-amino- $\mathrm{N}$ (AAN) to (a) arterial flow, (b) net portal-drained viscera (PDV) flux, (c) hepatic inflow and (d) outflow. 
(a) Net PDV fluxes

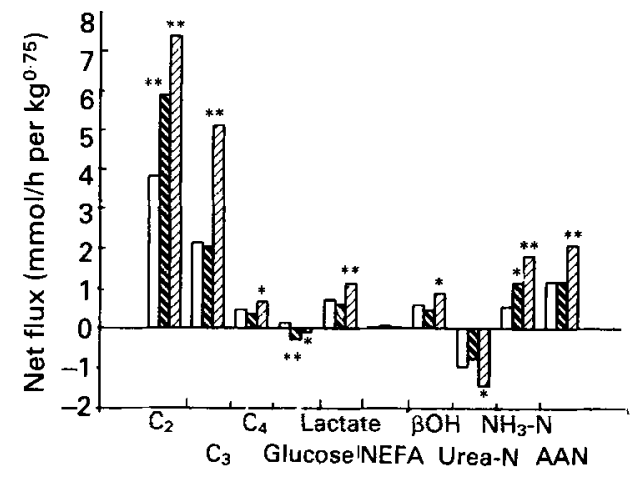

(c) Net splanchnic fluxes

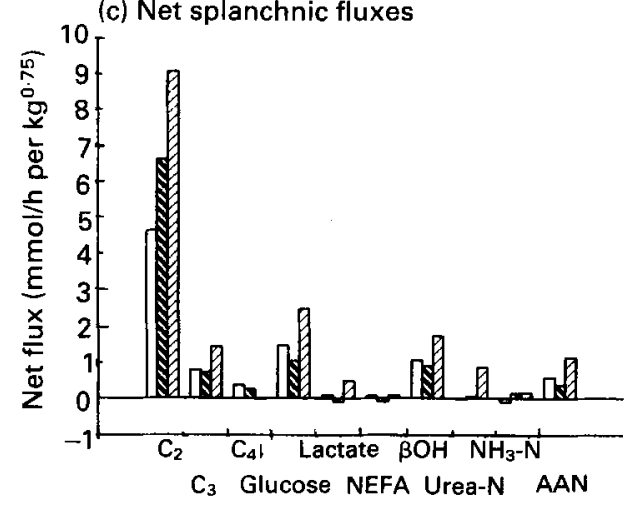

(b) Net hepatic fluxes

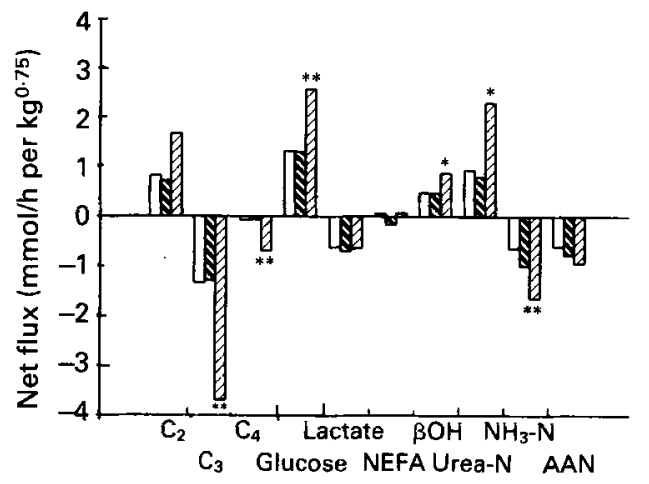

(d) Hepatic outflow

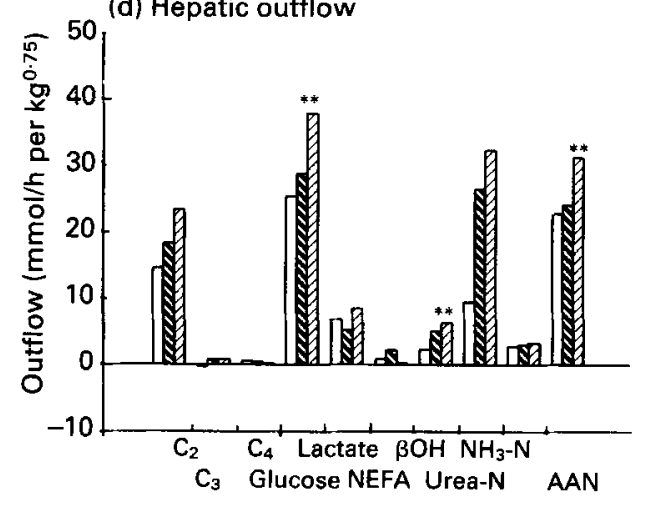

Fig. 2. Predicted effects of metabolizable energy intake (MEI; 481 and $962 \mathrm{~kJ} / \mathrm{d}$ per $\mathrm{kg}^{0.75}$ ) and dietary crude fibre contents (CF; 100 v. $350 \mathrm{~g} / \mathrm{kg}$ ) at constant dietary crude protein level (nitrogen $\times 6 \cdot 25 ; \mathrm{CP} ; 100 \mathrm{~g} / \mathrm{kg}$ ) on (a) net portal-drained viscera (PDV), (b) hepatic, and (c) splanchnic nutrient fluxes, and (d) flows of nutrients leaving the liver. Values were calculated directly from prediction equations except for net splanchnic fluxes which are the sum of the net portal and hepatic fluxes. Nutrients considered are acetate $\left(C_{2}\right)$, propionate $\left(C_{3}\right)$, $n$-butyrate $\left(\mathrm{C}_{4}\right)$, glucose, lactate, non-esterified fatty acids (NEFA), $\beta$-hydroxybutyrate $(\beta O H)$, urea-N, $\mathrm{NH}_{3}-\mathrm{N}$ and $\alpha$-amino-N (AAN). The effects of changes in MEI and $\mathrm{CF}$ were significant: ${ }^{*} P<0 \cdot 05,{ }^{* *} P<0 \cdot 01$. ( $\square$ ), MEI $481 \mathrm{~kJ} / \mathrm{d}$ per kg ${ }^{0.75}$, CF $100 \mathrm{~g} / \mathrm{kg}$, CP $100 \mathrm{~g} / \mathrm{kg}$; (\$), MEI $481 \mathrm{~kJ} / \mathrm{d}$ per kg ${ }^{0.75}$, CF $350 \mathrm{~g} / \mathrm{kg}, \mathrm{CP} 100$ $\mathrm{g} / \mathrm{kg}$; (B), MEI $962 \mathrm{~kJ} / \mathrm{d}$ per kg ${ }^{0.75}, \mathrm{CF} 100 \mathrm{~g} / \mathrm{kg}, \mathrm{CP} 100 \mathrm{~g} / \mathrm{kg}$. For details of equations, see Table 1.

interactions may exist with the use of maize-based diets at high MEI since gut glucose uptake responds positively to increased arterial glucose (Balcells et al. 1992), but this may be limited in its extent (Janes et al. 1985). The effect of increased glucose supply to the gut would predominate here over that of increased propionate supply since intra-ruminal propionate infusions lower gut glucose uptake (Seal \& Parker, 1992).

Of interest is the quantitative importance of net $\mathrm{NH}_{3}-\mathrm{N}$ absorption across the PDV (Fig. 2(a)) which represented on average 53 (range 31-65)\% of net $\mathrm{NH}_{3}$ plus $\alpha-\mathrm{NH}_{2}-\mathrm{N}$ absorption; this proportion was not altered by intake. An even wider range had been noted by Huntington (1986). The improved net PDV $\alpha-\mathrm{NH}_{2}-\mathrm{N}$ absorption at the higher MEI intake might be associated with higher total dietary and microbial protein flow to the duodenum and with the increased net PDV propionate absorption. Indeed, the availability of rumen propionate, at constant dietary and microbial $\mathrm{N}$ absorption from 
the digestive tract (Seal et al. 1993a), enhances the net PDV release of free amino acids (Seal \& Parker, 1991) probably by sparing gut-tissue amino acids from breakdown.

Of the major contributors to energy released in portal vein (Fig. 1(b)) only the proportion of energy absorbed as propionate was notably higher at the high intake (34 v. $26 \%$ ). The molar proportion of acetate absorbed across the PDV was lower at the high intake $(55 v .65 \%)$ whereas that of propionate was higher (39v. 28\%); butyrate did not change. This was also noted as an effect of the level of intake by Reynolds et al. $(1993 a, b)$ using both forage and concentrate diets, suggesting that gut requirements for acetate increase with intake. We may have overestimated this effect since increasing plane of feeding generally corresponds to a switch from a low-concentrate diet to a highconcentrate diet (Gross et al. 1990).

Assuming that all substrates oxidized are of dietary origin, we predict that $79-84 \%$ of MEI would be directed to the liver with no clear effect of intake on this proportion.

\section{Nutrient supply to the liver}

Of the total energy supply to the liver, net portal absorption accounted for only $7-11 \%$, with the higher contribution noted at high intake. Consequently changes in the availability of absorbed endproducts of digestion were highly buffered by the arterial blood metabolite supply. It should first be mentioned that hepatic venous blood flows increased significantly with intake (Table 1, equation 2), whereas hepatic arterial blood flows did not seem to be affected (Table 1, equation 3), probably because the methodology used ( $p$-aminohippuric acid) leads to a wide scatter of data. Over all, results suggested that increased intake resulted in a significantly higher supply of most metabolites to the liver $(P<0 \cdot 05)$, except for lactate, NEFA and urea-N.

Because of the large contribution of arterial blood, glucose was the predominant contributor to the energy supply to the liver (42\%), followed by $\alpha-\mathrm{NH}_{2}-\mathrm{N}$ (29\%; Fig. $1(c))$. Generally, the contributions of propionate, glucose and $\beta$-hydroxybutyrate slightly increased with high intake while that of NEFA decreased.

\section{Net nutrient fluxes through the liver}

Changes in hepatic metabolism depended on the metabolite considered (Fig. 2(b)). Net hepatic production of acetate would always be predicted, masking simultaneous uptake and release (Seal \& Reynolds, 1993); it was not significantly increased with intake. On the other hand, butyrate uptake and net $\beta$-hydroxybutyrate production, to which butyrate contributes for 26-48\% (Seal \& Reynolds, 1993), significantly increased with intake $(P<0 \cdot 05)$.

Net hepatic glucose production was enhanced $(P<0 \cdot 01)$ at elevated planes of feeding probably as a consequence of higher availability and uptake of precursors such as propionate $(P<0 \cdot 01)$ and $\alpha-\mathrm{NH}_{2}-\mathrm{N}$ (NS). This is consistent with the high hepatic extraction rate of propionate (85-100\% of net PDV absorption; Seal \& Reynolds, 1993) and with the fact that propionate availability regulates gluconeogenesis from other precursors (Brockman, 1993). Here again a bias may exist due to the usual association of higher intakes with high-concentrate diets since the contribution of propionate to hepatic gluconeogenesis was found to decrease with intake of forage diets but to increase with concentrate diets (Reynolds et al. 1991, 1992b). 
Urea- $\mathrm{N}$ production was higher at the higher intakes $(P<0.01)$, in parallel with increased $\mathrm{NH}_{3}-\mathrm{N}(P<0.01)$ and $\alpha-\mathrm{NH}_{2}-\mathrm{N}(\mathrm{NS})$ uptake. Liver $\mathrm{NH}_{3}-\mathrm{N}$ removal generally balanced net PDV $\mathrm{NH}_{3}-\mathrm{N}$ absorption (van der Walt, 1993), accounting, on average, for $76 \%$ of calculated liver urea release whereas $\alpha-\mathrm{NH}_{2}-\mathrm{N}$ accounted for a further $46 \%$. Slightly lower or similar estimates were obtained by Reynolds et al. (1991). Rates of protein turnover in liver are extremely high. Protein degradation rates seem to be lower at high intakes (Lobley et al. 1994), but there is no clear effect on the contribution of $\alpha-\mathrm{NH}_{2}-\mathrm{N}$ to urea-N release. Generally a high proportion of the $\alpha-\mathrm{NH}_{2}-\mathrm{N}$ released by PDV is taken up by liver, but, the proportion seems to be lower at the high intakes $(56 \mathrm{v}$. $71 \%$ ), improving the availability of amino acids to peripheral tissues. However, experimental evidence does not clearly support this trend (Burrin et al. 1991; Reynolds et al. 1991, 1992b).

Oxidative metabolism of the liver represented $16-21 \%$ of MEI such that only $57-67 \%$ of MEI would then be available to peripheral tissues.

\section{Release of nutrients to peripheral tissues}

The flows of metabolites leaving the liver (Fig. 2(d)) combine the arterial splanchnic nutrient supply and the net nutrient fluxes through splanchnic tissues (Fig. 2(c)); they were altered by feeding level. Net hepatic release of acetate would be higher at the high intake but its percentage contribution (12-14) to the hepatic energy outflow is relatively unchanged. Except for propionate and butyrate, most other metabolite hepatic outflows were higher at higher intakes, with significant effects being noted for glucose $(P<0 \cdot 01)$, $\beta$-hydroxybutyrate $(P<0.01)$ and $\alpha-\mathrm{NH}_{2}-\mathrm{N} \quad(P<0 \cdot 01)$. Only NEFA flow tended to decrease, but not significantly. Consequently, the balance of the energy metabolites was not greatly modified with intake, apart from an increase in the contribution of $\beta$-hydroxybutyrate from 3.5 to $6.5 \%$. The data-set used to predict changes in metabolites leaving the liver was smaller than that available on arterial concentrations and did not show the increases in propionate and glucose arterial concentrations with increasing intake.

\section{Net nutrient fluxes through hindquarters}

To examine the effects of nutritional changes on peripheral tissue metabolism, hindquarters data were collected. There were, however, too few data to establish regression equations. Only metabolite supply to hindquarters can be discussed because it involves blood flows and arterial metabolite concentrations. Blood flow to hindquarters appeared to be statistically unaffected by intake (Table 1, equation 4), even though increasing evidence suggests a rise with intake (for review, see Ortigues \& Durand, 1995). Consequently, changes in nutrient supply here would arise mostly from metabolite arterial concentrations. Increases in glucose supply and, to a much smaller extent, propionate supply were predicted at the high intake as well as a decrease in NEFA supply (Fig. 1(a)). These predictions suggest that the possibility of increasing nutrient supply to hindquarters by altering the plane of feeding is limited. This point would need to be widely tested experimentally using precise methodologies. 


\section{Tissue and whole-animal energy expenditure}

$\mathrm{PDV} \mathrm{O}_{2}$ consumption increased with intake (Table 1, equation 5). The heat increment of PDV, calculated using the McLean (1986) coefficient, amounted to 137 (SE 13.9) J/d per $\mathrm{kg}^{0.75}$ for each increment of $1 \mathrm{~kJ} \mathrm{MEI} / \mathrm{d}$ per $\mathrm{kg}^{0.75}$, which was slightly higher than that calculated by Seal \& Reynolds (1993). It was related to increases in both blood flows and $\mathrm{O}_{2}$ extraction ratio (Table 1 , equation 8 ). It is worth noting, however, that this energy expended for oxidative purposes represents only $2-3 \%$ of the total energy supplied to PDV.

The rise in energy expenditure of PDV with intake was associated here with a general increase in the net absorption of energy-yielding nutrients. The latter appeared to be generally proportional to the increase in MEI, except for an increase in the proportion of energy absorbed as propionate and a decrease in that of glucose. The higher oxidative requirements appeared to be met from glucose, presumably of systemic origin, and probably acetate. They are known to be associated with changes in gut mass (Ortigues \& Doreau, 1995), and stress the need to study the effect of MEI on gut protein metabolism (Lobley et al. 1994).

Energy expenditure by liver increased with intake to an extent similar to that of PDV, i.e. by 122 (SE 18.2) J/d per $\mathrm{kg}^{0.75}$ for each increment of $1 \mathrm{~kJ} \mathrm{MEI/d}$ per $\mathrm{kg}^{0.75}$ (from equation 6 , Table 1 ), and was partly related to enhanced hepatic $\mathrm{O}_{2}$ extraction ratios (equation 9, Table 1). It should not be extrapolated to lower intakes than those used here $\left(<184 \mathrm{~kJ} / \mathrm{d}\right.$ per $\left.\mathrm{kg}^{0 \cdot 75}\right)$ since experimental results suggest that a $3 \mathrm{~d}$ fast activates hepatic metabolism leading to higher 'basal' energy expenditure $(110 \mathrm{~kJ}$; Eisemann \& Nienaber, 1990; Huntington et al. 1990) than that predicted from the intercept of equation $6(50 \mathrm{~kJ}$; Table 1).

Hepatic $\mathrm{O}_{2}$ consumption was highly correlated with net hepatic glucose $(r 0 \cdot 81)$ and net urea- $\mathrm{N}(r \quad 0.62)$ production and to a lower extent with $\alpha-\mathrm{NH}_{2}-\mathrm{N}$ uptake $(r 0.56)$. Consequently, level of feeding seemed primarily to enhance the hepatic metabolic pathways involved in glucose and $\mathrm{N}$ metabolism. It is associated also with changes in liver mass (Johnson et al. 1990; Ortigues \& Doreau, 1995).

In the hindquarters, energy expenditure appeared to remain unaltered with feeding level (Table 1, equation 7). Available experimental evidence reviewed by Ortigues \& Durand (1995) generally showed no influence of feeding level on $\mathrm{O}_{2}$ consumption in the hindquarters; however, changes in the posture or physical activity may introduce a bias in the results.

Consequently, at the whole-animal level it can be calculated for high-concentrate diets having an efficiency of energy utilization for growth and fattening of 0.5 (Institut National de la Recherche Agronomique, 1978) that half the increase in energy expenditure above maintenance would originate from both PDV and liver, with similar contributions from each. The remainder of the heat increment could not be attributed to carcass metabolism (Ortigues \& Doreau, 1995) and its origin remains to be elucidated.

\section{EFFECT OF DIETARY CRUDE FIBRE CONTENT}

The effects of CF were mostly limited to PDV. Small significant effects were noted in the liver for $\beta$-hydroxybutyrate and NEFA. However, the latter did not appear consistently at all levels and, therefore, will not be discussed. 


\section{Nutrient supply and net fluxes through portal-drained viscera}

First it is noteworthy that CF had no effect on portal blood flow (Table 1, equation 1). Contradictory results were found in the literature (Reynolds \& Huntington, 1988a; Huntington, 1989; Reynolds et al. 1991; Reynolds \& Tyrrell, 1991; Seal et al. 1992). With forage diets, peristalsis and, hence, smooth muscle contraction work is enhanced by bulk, which could have increased blood flows through the muscular tissues of the gut. However, there were no detectable overall changes probably because mass-specific blood flow of the muscular layers is only $1.7-6.9 \%$ that of the highly vascularized epithelium (Ortigues \& Doreau, 1995). On the other hand the balance of nutrients available for absorption (acetate, propionate, butyrate and glucose) had no effect on portal blood flows (Huntington et al. 1983; Harmon \& Avery, 1987; Gross et al. 1990; Krehbiel et al. 1992).

No significant changes in arterial-blood-metabolite concentrations were predicted with change in CF. There were only tendencies (NS) for acetate and NEFA concentrations to increase. Consequently, most changes noted at the PDV level with change in CF were due to the balance of endproducts of digestion, with predominantly an increase in acetate production (Institut National de la Recherche Agronomique, 1978).

Higher CF content increased the net PDV release of acetate (Fig. 2(a)) which then represented a much larger percentage of the energy absorbed $(40 \mathrm{v} .26 \%)$, at the expense of most nutrients except $\alpha-\mathrm{NH}_{2}-\mathrm{N}$. Net glucose utilization by PDV tissues increased with increased CF as shown in vitro in rumen tissues (Harmon, 1986). This is also consistent with a lower glucose availability in forage $v$. maize-based-concentrate diets. Indeed, the net glucose PDV extraction noted with forage diets switched to a net glucose absorption when duodenal starch flow was increased (Janes et al. 1985; Seal et al. 1993b). Thus, it is unlikely that the increased acetate availability would have been sufficient to substantially spare glucose from oxidation (Huntington et al. 1983).

High $\mathrm{CF}$ significantly increased net appearance of $\mathrm{NH}_{3}-\mathrm{N}$ in portal blood, while $\alpha-\mathrm{NH}_{2}-\mathrm{N}$ net flux was unaffected as shown experimentally by Reynolds et al. (1991). The increase in dietary CF content is associated here with the frequent use of lucerne, with a high $\mathrm{CP}$ content. Consequently, at equal $\mathrm{MEI}, \mathrm{N}$ intake was higher in forage than in concentrate diets. In most diets used, rumen capture of $\mathrm{NH}_{3}$ by rumen micro-organisms would be primarily limited by ME availability, thus explaining the higher $\mathrm{NH}_{3}-\mathrm{N}$ absorption predicted. A significant correlation $(r 0.48)$ between net $\mathrm{NH}_{3}-\mathrm{N}$ absorption across PDV and the N:ME intake ratio confirms this point. A direct effect of acetate is unlikely since intraruminally-infused acetate did not modify the net portal appearance of $\mathrm{NH}_{3}-\mathrm{N}$ (Huntington et al. 1983). The contribution of $\alpha-\mathrm{NH}_{2}-\mathrm{N}$ to the net energy absorbed remained unaltered at $18 \%$.

\section{Net nutrient fluxes through the liver}

None of the hepatic metabolite uptakes or releases appeared to be influenced by CF (Fig. 2(b)). Flows of nutrients leaving the liver towards peripheral tissues (Fig. 2(d)) were not statistically altered by CF. The increased net PDV absorption of acetate was not sufficient to alter the contribution of acetate to the energy flow leaving the liver. In an experiment designed to predict the effect of dietary hay:concentrate ratio on urea flux in steers, liver output of urea- $\mathrm{N}$ was found to be minimal when concentrate was less than 
$200 \mathrm{~g} / \mathrm{kg}$ and to increase to a maximum when concentrate was $500 \mathrm{~g} / \mathrm{kg}$ (Huntington et al. 1993). Such an effect was not detected here as there was a large variability associated with urea results.

\section{Nutrient supply to hindquarters}

Hindquarters blood flow appeared to be unresponsive to changes in CF with the possible exception of slight changes in arterial concentrations, e.g. the percentage of glucose in the energy supply to the hindquarters decreased from 47 to $42 \%$, while that of NEFA tended to increase from 8 to $14 \%$. Contributions of acetate and $\alpha-\mathrm{NH}_{2}-\mathrm{N}$ to this energy supply would remained stable at approximately 6 and $30 \%$ respectively.

\section{Tissue and whole-animal energy expenditure}

Higher dietary $\mathrm{CF}$ content increased $\mathrm{O}_{2}$ consumption by PDV (Table 1, equation 5). The increment in energy expenditure was unrealistically high with a large variability at 880 (SE 298.1) $\mathrm{J} / \mathrm{d}$ per $\mathrm{kg}^{0.75}$ for each percentage unit increase in CF. It was associated with a higher glucose uptake and a higher value for net acetate: $\alpha-\mathrm{NH}_{2}-\mathrm{N}$ absorbed across the PDV. Higher energy requirements of PDV could possibly be related to enhanced muscular work to sustain a higher peristalsis. Other factors could have been assumed to alter PDV energy expenditure with changes in $\mathrm{CF}$; for example, changes in gut mass through a bulk effect. However, in ruminants the influence of the dietary forage:concentrate ratio on gut mass has led to unclear results (Ortigues \& Doreau, 1995). A direct stimulatory effect of rumen butyrate on in vivo epithelial cell proliferation (Galfi et al. 1991 ) is also unlikely considering the lack of significant changes in the net PDV butyrate and $\beta$-hydroxybutyrate fluxes. Finally, increased energy expenditure associated with cellular transport activities is little affected by the pattern of available nutrients (McBride \& Kelly, 1990).

Hepatic energy expenditure was unresponsive to diet composition (from equation 6 , Table 1) in agreement with the lack of significant changes in net hepatic nutrient fluxes. Direct experimental evidence for a clear effect of the forage:concentrate ratio is also lacking (Ortigues \& Doreau, 1995). Similarly, energy expenditure of hindquarters was unaffected by $C F$ content (Table 1 , equation 7 ). Consequently, the known lower efficiency of energy utilization for forage diets at the whole-animal level would be attributed here to increased energy expenditure of PDV. Nevertheless, quantification of the latter value would have to be checked experimentally since the predicted increment appears to be much higher than the calculated increase in whole-animal energy expenditure when average $k_{f}$ drops from 0.5 with concentrate diets to 0.4 with forage diets.

\section{EFFECT OF DIETARY CRUDE PROTEIN CONTENT}

The influence of the dietary CP content seemed to be limited to the following metabolites: urea- $\mathrm{N}, \mathrm{NH}_{3}-\mathrm{N}$ and $\beta$-hydroxybutyrate.

\section{Nutrient supply and net fluxes through portal-drained viscera}

An increased dietary CP content at fixed MEI and CF content was predicted to result in higher net portal appearance of $\mathrm{NH}_{3}-\mathrm{N}(P<0 \cdot 01)$, while that of $\alpha-\mathrm{NH}_{2}-\mathrm{N}$ would remain 
(a) Net PDV fluxes

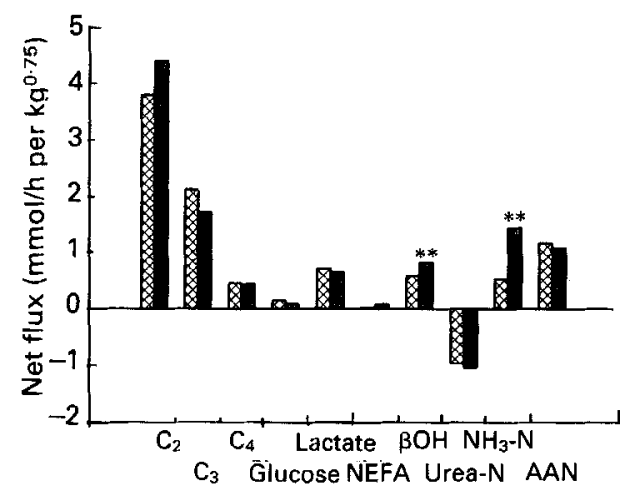

(c) Net splanchnic fluxes

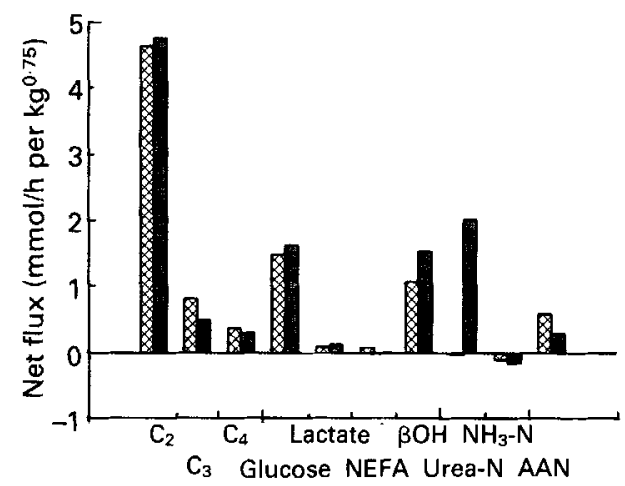

(b) Net hepatic fluxes

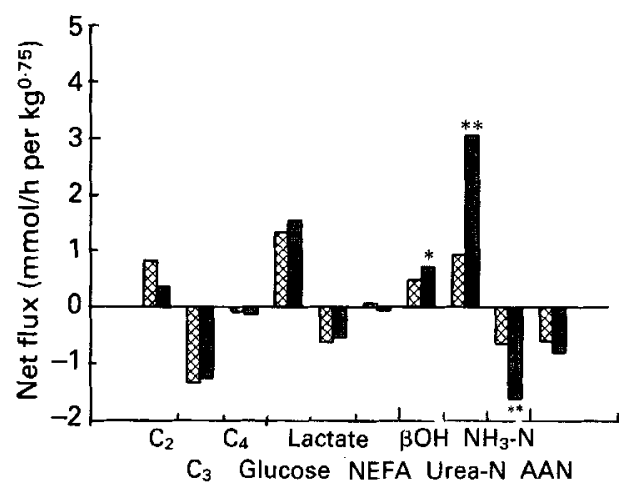

(d) Hepatic outflow

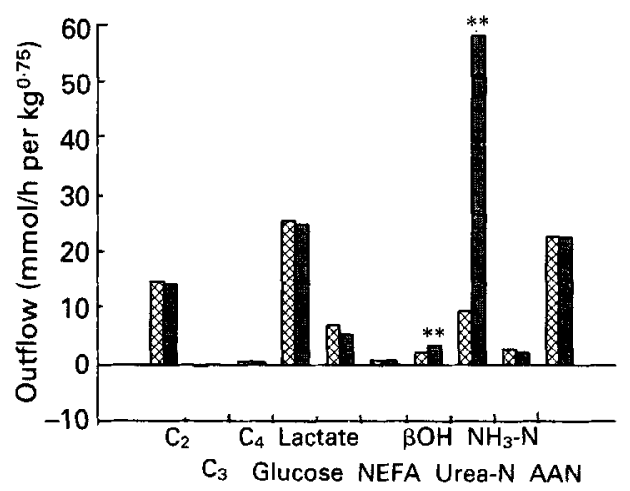

Fig. 3. Predicted effects of dietary crude protein level (nitrogen $\times 6.25 ; \mathrm{CP} ; 100(\mathbb{X})$ and $150(\mathbf{\square}) \mathrm{g} / \mathrm{kg}) \mathrm{at}$ constant metabolizable energy intake (MEI; $481 \mathrm{~kJ} / \mathrm{d}$ per $\mathrm{kg}^{0.75}$ ) and dietary crude fibre content (CF; $\left.100 \mathrm{~g} / \mathrm{kg}\right)$ on (a) net portal-drained viscera (PDV), (b) hepatic, and (c) splanchnic nutrient fluxes, and (d) flows of nutrients leaving the liver. Values were calculated directly from prediction equations except for net splanchnic fluxes which are the sum of the portal and hepatic fluxes. Nutrients considered are acetate $\left(\mathrm{C}_{2}\right)$, propionate $\left(C_{3}\right), n$-butyrate $\left(C_{4}\right)$, glucose, lactate, non-esterified fatty acids (NEFA), $\beta$-hydroxybutyrate $(\beta O H)$, urea- $N$, $\mathrm{NH}_{3}-\mathrm{N}$ and $\alpha$-amino-N (AAN). The effects of changes in $\mathrm{CP}$ were significant: ${ }^{*} P<0 \cdot 05,{ }^{* *} P<0 \cdot 01$.

statistically unchanged (Fig. 3(a)). Since the diets considered were generally not deficient in rumen-degradable $\mathrm{N}$, rumen $\mathrm{NH}_{3}$ capture by micro-organisms and microbial protein synthesis would depend primarily on ME supply. Seal \& Reynolds (1993) also indicated that amino acid release by PDV was not correlated with dietary N supply but with MEI. The high- $\mathrm{CP}$ diets considered in the present data-set generally did not include rumenundegradable protein sources. Even so, no clear relationships seem to exist between rumen degradability of $\mathrm{N}$ sources and net portal amino acid absorption (Huntington, 1987). Improved net appearance of $\alpha-\mathrm{NH}_{2}-\mathrm{N}$ in portal blood had only been noted in cases of abomasal casein infusion (Guerino et al. 1991) or of dietary supplementation with protected soyabean meal (Cleale et al. 1987) or methionine and lysine (Maltby et al. 1991). Changes in protein metabolism of the gut wall may explain the limited changes of net PDV $\alpha-\mathrm{NH}_{2}-\mathrm{N}$ absorption since a greater metabolism of amino acids has been reported with higher CP contents (van der Walt, 1993). 
High CP content also resulted unexpectedly (Maltby et al. 1991) in an increased net portal appearance of $\beta$-hydroxybutyrate $(P<0 \cdot 01)$.

\section{Nutrient supply and net fluxes through liver}

In the liver, removal of blood $\mathrm{NH}_{3}-\mathrm{N}$ and net production of urea were significantly enhanced $(P<0 \cdot 01)$ by higher CP; net release of $\beta$-hydroxybutyrate also increased (Fig. 3 (b); $P<0.01$ ). This minor change (from 3.5 to $5.2 \%$ ) in the energetic contribution of the nutrients to total energy flow reaching or leaving the liver was the only one affected by CP.

No changes were predicted here in terms of flow of $\alpha-\mathrm{NH}_{2}-\mathrm{N}$ reaching the liver or net hepatic $\alpha-\mathrm{NH}_{2}-\mathrm{N}$ flux. In the literature, an increase in net PDV absorption of $\alpha-\mathrm{NH}_{2}-\mathrm{N}$ was generally countered by greater hepatic uptake for gluconeogenesis (Judson \& Leng, 1973 ) or possibly hepatic protein synthesis (Guerino et al. 1991) such that splanchnic release to peripheral tissues was not significantly modified. This point would warrant further studies coupled in particular with net peptide (Webb et al. 1986) fluxes through splanchnic tissues. In the present predictions, the proportions of the various energy nutrients leaving the liver were not altered (Fig. 3(c and d)).

When $\mathrm{N}$ intake was chosen as the independent variable in the multiple regressions instead of CP, correlations were not modified, confirming that MEI is the primary predictive variable of interest for most energy nutrients. The most notable effect of $\mathrm{N}$ intake or CP level is on the variable efficiency of rumen $\mathrm{NH}_{3}$ capture.

\section{Nutrient supply to hindquarters}

One interesting effect of the dietary $\mathrm{CP}$ level that would require experimental validation is the stimulation of hindquarters blood flow $(P<0.05$; Table 1 , equation 4$)$ which would increase nutrient supply to the hindquarters without any changes in the balance of energetic nutrients available. There has been one report of this effect on blood flow (Ahmed et al. 1983). Transient redistribution of cardiac output among body tissues in favour of peripheral tissues, associated with excess $\mathrm{NH}_{3}$ loading (Orzechowski et al. 1987; Fernandez et al. 1990) could be under adrenergic regulation (Barej et al. 1980). In the present case arterial urea- $\mathrm{N}$ but not $\mathrm{NH}_{3}-\mathrm{N}$ concentrations were increased $(P<0.05)$ with increased CP. It is interesting to note that the coefficients for $\mathrm{CP}$ in the multiple regressions established for portal and hepatic blood flows were negative, although high standard errors were associated with these estimates.

\section{Tissue and whole-body energy expenditure}

The dietary CP level appeared, generally, to have no effect on $\mathrm{PDV} \mathrm{O}_{2}$ consumption (Table 1, equation 5). Dietary supplementation with urea or protected amino acids (Maltby et al. 1991) or absomasal infusion of casein (Guerino et al. 1991) were also without any effect, whereas raising the soyabean meal content of a $750 \mathrm{~g}$ concentrate $/ \mathrm{kg}$ diet led to higher PDV O 2 consumption (Reynolds et al. 1992a).

Energy expenditure by liver was unresponsive to diet CP level (from Table 1, equation 6). The nature of the $\mathrm{N}$ sources as well as $\mathrm{N}$ intake were thought to influence hepatic $\mathrm{O}_{2}$ consumption via hepatic ureagenesis; however, theoretical considerations suggest that 
this may depend on the oxaloacetate precursor (Reynolds, 1992). Increased N supply, as soyabean meal (Reynolds et al. 1992a), urea or protected amino acids (Maltby et al. 1991) or as abomasal casein infusion (Guerino et al. 1991) failed to show significant increases in hepatic $\mathrm{O}_{2}$ consumption, lending support to the present prediction.

In the hindquarters, energy expenditure appeared to increase with the dietary $\mathrm{CP}$ level (Table 1, equation 7); however, this was associated with a large standard error which limits quantitative interpretation. This trend parallels that for blood flows. There is no experimental evidence of an effect of dietary CP content on hindquarters energy expenditure and this point would warrant confirmation.

Overall, the responses predicted here do not clarify the small and variable effects of $\mathrm{CP}$ on the efficiency of energy utilization by the growing ruminants (Ortigues et al. 1990).

\section{CONCLUSIONS}

The approach used here attempted to build a generalized quantitative picture of the influence of nutritional factors on net nutrient fluxes through tissues and tissue energy expenditure in the fed growing ruminant. The hypotheses involved in establishing the data-set and the type of data available suggest that the outcome of this work could be considered as a research tool to identify areas of research where information is scarce. For example, studies on concentrate diets using grain sources other than maize, or diets based on forages other than lucerne would be necessary, as well as more systematic studies on level of intake, $\mathrm{CF}$ and $\mathrm{CP}$ contents. The quantitative influence of nutrition on nutrients such as L-lactate, $\beta$-hydroxybutyrate, NEFA and other lipid constituents also remains unclear. Nutritional influence on the energy metabolism of peripheral tissues, especially muscles, is also a key area to explore.

Finally, it has established general trends, even though only the most significant effects could be detected because the origin of the data was wide ranging and interpretation was limited by both the small number of observations and involvement of the most commonly used feed ingredients. A more detailed analysis would be necessary to improve this interpretation. Nevertheless, some questions were raised, such as the role of PDV in determining the difference between the efficiency of energy utilization of forage and concentrate diets in relation to acetate absorption. The possibility of altering the partition of nutrients in favour of muscle by nutritional means seemed limited. It is probably highly dependent on the rate and distribution of blood flows to tissues and would need to be tested, especially in the context of growing ruminants raised for meat production. Finally the exogenous supply of nutrients to tissues appeared to be greatly diluted by the arterial blood supply, leading to smaller changes in blood metabolite concentrations and in nutrient balance, thus raising the issue of what controls changes in nutrient use by tissues. Combined investigations on the role of splanchnic-released hormones on the control of nutrient partition and use would seem particularly appropriate.

\section{REFERENCES}

Ahmed, B. M., Berger, W. G. \& Ames, N. K. (1983). Effect of nutritional state and insulin on hind-limb amino-acid metabolism in steers. Journal of Nutrition 113, 1529-1543.

Balcells, J., Seal, C. J. \& Parker, D. S. (1992). Effect of intravenous glucose infusion on glucose metabolism by portal drained viscera of sheep fed a low quality roughage. Journal of Animal Science 70, Suppl. 1, 294. 
Barej, W., Siwecka, B., Gronczewski, J. \& Skolasinka, K. (1980). The depressive action of ammonium chloride on the hepatic blood flow in sheep. Quarterly Journal of Experimental Physiology 65, 99-104.

Bergman, E. \& Wolff, J. E. (1971). Metabolism of volatile fatty acids by liver and portal-drained viscera in sheep. American Journal of Physiology 221, 586-592.

Brockman, R. P. (1993). Glucose and short-chain fatty acid metabolism. In Quantitative Aspects of Ruminant Digestion and Metabolism, pp. 250-265 [J. M. Forbes and J. France, editors]. Wallingford: CAB International.

Burrin, D. G., Ferrell, C. L., Eisemann, J. H. \& Britton, R. A. (1991). Level of nutrition and splanchnic metabolite flux in young lambs. Journal of Animal Science 69, 1082-1091.

Cleale, R. M., Britton, R. A., Klopfenstein, T. J., Bauer, M. L., Harmon, D. L. \& Satterlee, L. D. (1987). Induced non-enzymatic browning of soybean meal. II. Ruminal escape and net portal absorption of soybean protein treated with xylose. Journal of Animal Science 65, 1319-1326.

Eisemann, J. H. \& Nienaber, J. A. (1990). Tissue and whole-body oxygen uptake in fed and fasted steers. British Journal of Nutrition 64, 399-411.

Fernandez, J. M., Croom, W. J., Tate, L. P. \& Johnson, A. D. (1990). Subclinical ammonia toxicity in steers: effects on hepatic and portal-drained visceral flux of metabolites and regulatory hormones. Journal of Animal Science 68, 1726-1742.

Forbes, J. M. \& France, J. (editors) (1993). Quantitative Aspects of Ruminant Digestion and Metabolism. Wallingford: CAB International.

Galfi, P., Neogrady, S. \& Sakata, T. (1991). Effects of volatile fatty acids on the epithelium cell proliferation of the digestive tract and its hormonal mediation. In Physiological Aspects of Digestion and Metabolism in Ruminants, pp. 49-59 [T. Tsuda, Y. Sasaki and R. Kawashima, editors]. San Diego, CA: Academic Press.

Gross, K. L., Harmon, D. L., Minton, J. E. \& Avery, T. B. (1990). Effects of isoenergetic infusions of propionate and glucose on portal-drained visceral nutrient flux and concentrations of hormones in lambs maintained by total intragastric infusion. Journal of Animal Science 68, 2566-2574.

Guerino, F., Huntington, G. B., Erdman, R. A., Elsasser, T. H. \& Reynolds, C. K. (1991). The effects of abomasal casein infusions in growing beef steers on portal and hepatic flux of pancreatic hormones and arterial concentrations of somatomedin-C. Journal of Animal Science 69, 379-386.

Harmon, D. L. (1986). Influence of dietary energy intake and substrate addition on the in vitro metabolism of glucose and glutamine in rumen epithelial tissue. Comparative Biochemistry and Physiology 85B, 643-647.

Harmon, D. L. \& Avery, T. B. (1987). Effects of dietary monensin and sodium propionate on net nutrient flux in steers fed a high-concentrate diet. Journal of Animal Science 65, 1610-1616.

Huntington, G. B. (1986). Uptake and transport of nonprotein nitrogen by the ruminant gut. Federation Proceedings 45, 2272-2276.

Huntington, G. B. (1987). Net absorption from portal-drained viscera of nitrogenous compounds by beef heifers fed on diets differing in protein solubility or degradability in the rumen. British Journal of Nutrition $57,109-114$.

Huntington, G. B. (1989). Hepatic urea synthesis and site and rate of urea removal from blood of beef steers fed alfalfa hay or a high concentrate diet. Canadian Journal of Animal Science 69, 215-223.

Huntington, G. B., Eisemann, J. H. \& Whitt, J. M. (1990). Portal blood flow in beef steers: comparison of techniques and relation to hepatic blood flow, cardiac output and oxygen uptake. Journal of Animal Science 68, 1666-1673.

Huntington, G. B., Reynolds, P. J. \& Tyrrell, H. F. (1983). Net absorption and ruminal concentrations of metabolites in nonpregnant dry Holstein cows before and after intraruminal acetic acid infusion. Journal of Dairy Science 66, 1901-1908.

Huntington, G., Zetina, E., Potts, W. \& Whitt, J. (1993). Splanchnic urea flux in steers fed several switchgrass hay:concentrate ratios that provided equal daily amounts of energy and nitrogen. Journal of Animal Science 71, Suppl. $1,270$.

Institut National de la Recherche Agronomique (1978). Alimentation des Ruminants. Versailles: INRA Publications.

Janes, A. N., Weekes, T. E. C. \& Armstrong, D. G. (1985). Absorption and metabolism of glucose by the mesenteric-drained viscera of sheep fed on dried-grass or ground, maize-based diets. British Journal of Nutrition 54, 449-458.

Johnson, D. E., Johnson, K. A. \& Baldwin, R. L. (1990). Changes in liver and gastrointestinal tract energy demands in response to physiological workload in ruminants. Journal of Nutrition 120, 649-655.

Judson, G. J. \& Leng, R. A. (1973). Studies on the control of gluconeogenesis in sheep: effect of propionate, casein and butyrate infusions. British Journal of Nutrition 29, 175-195. 
Krehbiel, C. R., Harmon, D. L. \& Schnieder, J. E. (1992). Effect of increasing ruminal butyrate on portal and hepatic nutrient flux in steers. Journal of Animal Science 70, 904-914.

Lobley, G. E., Connell, A., Milne, E., Newman, A. M. \& Ewing, T. A. (1994). Protein synthesis in splanchnic tissues of sheep offered two levels of intake. British Journal of Nutrition 71, 3-12.

McBride, B. W. \& Kelly, J. M. (1990). Energy cost of absorption and metabolism in the ruminant gastrointestinal tract and liver: a review. Journal of Animal Science 68, 2997-3010.

McLean, J. A. (1986). The significance of carbon dioxide and methane measurements in the estimation of heat production in cattle. British Journal of Nutrition 55, 631-633.

MacRae, J. C., Lobley, G. E., Bruce, L. A., Luo, Q., Calder, A. G. \& Farningham, D. A. H. (1993). Leucine kinetics across the portal drained viscera of sheep. Journal of Animal Science 71, Suppl. 1, 279.

Maltby, S. A., Lomax, M. A., Beever, D. E. \& Pippard, C. J. (1991). The effect of increased ammonia and amino acid supply on postprandial portal-drained viscera and hepatic metabolism in growing steers fed maize silage. In Energy Metabolism of Farm Animals, pp. 20-23 [C. Wenk and M. Boessinger, editors]. Zürich: Institut für Nutztierwissenschaften.

Ortigues, I. (1991). Adaptation du métabolisme énergétique des ruminants à la sous-alimentation. Quantification au niveau de l'animal entier et de tissus corporels (Adaptation of energy metabolism to undernutrition in ruminants. Quantification in the whole animal and in individual body tissues). Reproduction Nutrition Development 31, 593-616.

Ortigues, I. \& Doreau, M. (1995). Responses of the splanchnic tissues of ruminants to changes in feeding level: absorption of digestion end-products, tissue mass, metabolic activity and implications to whole animal energy metabolism. Annales de Zootechnie (In the Press).

Ortigues, I. \& Durand, D. (1995). Adaptation of energy metabolism to undernutrition in ewes. Contribution of portal-drained viscera, liver and hindquarters. British Journal of Nutrition 73, 209-226.

Ortigues, I., Smith, T., Gill, M., Cammell, S. B. \& Yarrow, N. W. (1990). The effect of fishmeal supplementation of a straw-based diet on growth and calorimetric efficiency of growth in heifers. British Journal of Nutrition 64, 639-651.

Orzechowski, A., Motyl, T., Pierzynowski, G. \& Barej, W. (1987). Hepatic capacity for ammonia removal in sheep. Journal of Veterinary Medicine 34, 108-112.

Piccioli Cappelli, F., Seal, C. J. \& Parker, D. S. (1993). Portal absorption and utilization in sheep receiving exogenous glucose intravascularly or intraduodenally. Journal of Animal Science 71, Suppl. 1, 279.

Reynolds, C. K. (1992). Metabolism of nitrogenous compounds by ruminant liver. Journal of Nutrition 122 , 850-854.

Reynolds, C. K., Casper, D. P., Harmon, D. L. \& Milton, C. T. (1992a). Effect of CP and ME intake on visceral nutrient metabolism in beef steers. Journal of Animal Science 70, Suppl. 1, 315.

Reynolds, C. K. \& Huntington, G. B. (1988a). Partition of portal-drained visceral flux in beef steers. 1. Blood flow and net flux of oxygen, glucose and nitrogenous compounds across stomach and post-stomach tissues. British Journal of Nutrition 60, 539-551.

Reynolds, C. K. \& Huntington, G. B. (1988b). Partition of portal-drained visceral net flux in beef steers. 2. Net flux of volatile fatty acids, D- $\beta$-hydroxybutyrate and L-lactate across stomach and post-stomach tissues. British Journal of Nutrition 60, 553-562.

Reynolds, C. K., Lapierre, H., Tyrrell, H., Elsasser, T., Casper, D., Gaudreau, P. \& Brazeau, P. (1993a). Intake and growth hormone-releasing factor (GRF) affect visceral metabolism of VFA in growing beef steers. Journal of Animal Science 71, Suppl. 1, 270.

Reynolds, C. K., Lapierre, H., Tyrrell, H. F., Elsasser, T. H., Staples, R. C., Gaudreau, P. \& Brazeau, P. $(1992 b)$. Effects of growth hormone-releasing factor and feed intake on energy metabolism in growing beef steers: net nutrient metabolism by portal-drained viscera and liver. Journal of Animal Science 70, 752-763.

Reynolds, C. K. \& Tyrrell, H. F. (1991). Effects of mesenteric vein L-alanine infusion on liver metabolism in beef heifers fed on diets differing in forage:concentrate ratio. British Journal of Nutrition 66, 437-450.

Reynolds, C. K., Tyrrell, H. F. \& Reynolds, P. J. (1991). Effects of diet forage-to-concentrate ratio and intake on energy metabolism in growing beef heifers: net nutrient metabolism by visceral tissues. Journal of Nutrition 121, 1004-1015.

Reynolds, C. K., Tyrrell, H. F. \& Reynolds, P. J. (1993b). Effects of diet forage-to-concentrate ratio and intake on net visceral metabolism of VFA in growing beef heifers. Journal of Dairy Science 76, Suppl. 1, 283.

Seal, C. J. \& Parker, D. S. (1991). Increased plasma free amino acid concentrations and net absorption of amino acids into portal and mesenteric veins with intraruminal propionate infusion into forage-fed steers. In Protein Metabolism and Nutrition, pp. 184-186 [B. O. Eggum, S. Boisen, C. Borsting, D. A. Hvelplund and T. Hvelplund, editors]. Foulum: National Institute of Animal Science. 
Seal, C. J. \& Parker, D. S. (1992). Glucose utilization by portal drained viscera of steers receiving intraruminal propionate infusion. Journal of Animal Science 70, Suppl. 1, 294.

Seal, C. J., Parker, D. S. \& Avery, P. J. (1992). The effect of forage and forage-concentrate diets on rumen fermentation and metabolism of nutrients by the mesenteric- and portal-drained viscera in growing steers. British Journal of Nutrition 67, 355-370.

Seal, C. J., Parker, D. S., Balcells, J. \& Mole, J. L. (1993a). Nitrogen digestion in forage-fed sheep with and without intraruminal propionate infusion. Journal of Agricultural Science, Cambridge 120, 107-114.

Seal, C. J., Parker, D. S. \& Lobley, G. E. (1993b). Effect of intraduodenal starch infusion on glucose metabolism of growing steers fed alfalfa. Journal of Animal Science 71, Suppl. 1, 279.

Seal, C. J. \& Reynolds, C. K. (1993). Nutritional implications of gastrointestinal and liver metabolism in ruminants. Nutrition Research Reviews 6, 185-208.

van der Walt, J. G. (1993). Nitrogen metabolism of the ruminant liver. Australian Journal of Agricultural Research 44, 381-403.

Webb, K. E., Dirienzo, D. B. \& Matthews, J. C. (1986). Recent developments in gastrointestinal absorption and tissue utilization of peptides: a review. Journal of Dairy Science 76, 351-361. 